Original Research Paper

\title{
GIS-Based Optimal Site Selection for Installation of Large- Scale Smart Grid-Connected Photovoltaic (PV) Power Plants in Selangor, Malaysia
}

\author{
${ }^{1}$ Sabo Mahmoud Lurwan, ${ }^{2}$ Mohammed Oludare Idrees, \\ ${ }^{2}$ Goma Bedawi Ahmed, ${ }^{2}$ Usman Salihu Lay and ${ }^{1}$ Norman Mariun \\ ${ }^{1}$ Centre for Advanced Power and Energy Research (CAPER), Faculty of Engineering, University Putra Malaysia, Malaysia \\ ${ }^{I}$ Department of Electrical and Electronic Engineering, Faculty of Engineering, University Putra Malaysia, Malaysia \\ ${ }^{2}$ Geospacial Information Science Research Centre (GISRC), University Putra Malaysia, Serdang, Malaysia
}

Article history

Received: $10-10-2015$

Revised: 23-11-2016

Accepted: 16-01-2017

Corresponding Author: Sabo Mahmoud Lurwan Centre for Advanced Power and Energy Research, University Putra Malaysia, Selangor, Malaysia

Email: mahmoudlsabo@yahoo.com

\begin{abstract}
This study presents a GIS-based model to identify optimal sites to install large-scale smart grid-connected Photovoltaic (PV) power plants. Input datasets include digital elevation model, road networks, grid lines and daily average solar radiation. Using multi-criteria decision-making approach, we set constraining conditions for slope, proximity to the road, proximity to grid lines, solar radiation and land use to optimize the process of selecting suitable sites. Also, we predicted energy generation potential, installation capacity and $\mathrm{CO}_{2}$ emission reduction potential. The result shows that $790.48 \mathrm{~km}^{2}(40 \%)$ of the study is optimal for large-scale PV installation. Furthermore, a total of $105276.88 \mathrm{GWh} / \mathrm{yr}$ annual electricity generation, $59.29 \mathrm{GW}$ installation capacity and yearly $\mathrm{CO}_{2}$ emission reduction of $66324\left(\mathrm{kt}-\mathrm{CO}_{2} / \mathrm{yr}\right)$ are estimated for Selangor. This study indicates that based on the 2030 national energy demand, about $38.4 \%$ of the annual energy demand could be met if $59.29 \mathrm{GW}$ capacity is install in Selangor. Similarly, the study predicts $13.2 \%$ annual carbon emission reduction offset from the predicted $2020 \mathrm{CO}_{2}$ emission.
\end{abstract}

Keywords: Geographic Information System (GIS), Photovoltaic, Site Selection, Renewable Energy, $\mathrm{CO}_{2}$ Emission

\section{Introduction}

Global attention has been focusing on renewable sources of energy especially solar and the wind option. The challenges of meeting the increasing energy demands and the devastating effects of greenhouse gas emission to global climate from conventional energy sources have resulted in the wide use of Photovoltaic (PV) technology. Photovoltaic system, otherwise called solar power system, converts solar energy into electrical energy using semiconducting materials that exhibit the photovoltaic effect as alternative means of power generation (Zeman, 1987). In developed nations like USA, Germany, Spain, Japan, UK and others (IEA, 2014) solar energy has gained impressive applications at different scales (standalone and grid network). However, the pace of development in developing countries like Malaysia is very slow despite the abundance of this providence of nature.

Efforts to promote the development of alternative sources of energy using solar resources have recently been advancing in Malaysia due to two major reasons. One is the awakening reports from both global and local environmental fronts revealing that $226988.90 \mathrm{CO}_{2}-\mathrm{kt} / \mathrm{yr}$ of $\mathrm{CO}_{2}$ emitted into the atmosphere in the country alone as of 2013 (EDGAR, 2013). According to sources (e.g., Ali et al., 2012; Chua and Oh, 2010; Mekhilef et al., 2012; Noh, 2012; Ong et al., 2011), 95\% of the energy consumed in Malaysia comes from fossil sources (i.e., oil, coal and natural gas). Worst still is the prediction that by 2020 about 500 megatons of $\mathrm{CO}_{2}$ will be emitted into the atmosphere if no measures are taken (Ahmad et al., 2011; Ang et al., 2013; Mekhilef et al., 2012; Wee et al., 2008). The second reason is the increasing demand for power supply beyond the current generating capacity. The total electricity generated in 2013 was $111,020 \mathrm{GWh}$ (Energy-Commission, 2014) as against peak annual national energy demand of 16,562 MW. According to Ali et al. (2012; Mekhilef et al., 2012), with an anticipated $4.7 \%$ annual rise in industrial and commercial development, the predicted peak electricity 
demand could be up to 274 TWh by the year 2030 . Furthermore, uncertainty about the sustainability of fossil fuel to generate electrical power became more worrisome with the prediction of possible gas depletion by 2046 (Ali et al., 2012; Ong et al., 2011). These factors have triggered the need for proactive measures as witnessed in the present drives for Renewable Energy (RE) sources such as wind and solar energy.

Fortunately, Malaysia has good solar insolation; with approximately 4-5 $\mathrm{kWh} / \mathrm{m}^{2} /$ day (Affandi et al., 2013; Ali et al., 2012). Upon this reality, the 8th Malaysia plan projected 5\% Renewable Energy (RE) as the initial move to complement the energy mix by 2015 (Chen, 2012a). In the outcome of the national strategic plan (9th Malaysian plan 2006-2010), the country targeted 300 MW capacity of Renewable Energy (RE) to be connected to national grid across peninsular Malaysia. Moreover, a $40 \%$ reduction in the recorded carbon emission for year 2005 is projected to be achieved by the year 2020 (Amirruddin et al., 2011; Chen, 2012b). A major prerequisite to successful large-scale PV installation of this nature (i.e., $300 \mathrm{MW}$ ) is locating potential sites that will deliver optimum output. It may be a difficult task considering the multiple criteria involved in decision-making for practical implementation. More so, locations with apparently higher solar potential may not always be optimal for PV plants when considered in parallel with environmental, climatic and economic factors (Van Haaren and Fthenakis, 2011).

The capability of GIS as a decision support tool has been widely used to provide an answer to complex decision-making problems of this nature. For instance in Oman, PV site suitability analysis was conducted using GIS combined with FLOWA multi-criteria evaluation technique. The researchers found out that only about $0.5 \%$ of the total land area was highly suitable for installing large solar plants (Charabi and Gastli, 2011).
In a similar study conducted in Turkey (Uyan, 2013), GIS with Analytic Hierarchy Process (AHP) technique was employed. The research revealed four classes of suitability (low, moderate, suitable and best suitable) making up $15.38,14.38,15.98$ and $13.92 \%$ of the total study area respectively, while $40.34 \%$ of the area was found to be unsuitable. Likewise, by employing GIS with ELECTRE-TRI multi-criteria evaluation method, the municipality of Torre Pacheco, Spain, was reported to be the best site for PV solar farms placement (Sánchez-Lozano et al., 2014). The Iranian case study utilized GIS combined with AHP and Fuzzy Logic which reported that $18.25 \%$ of the total Shodirwan area is feasible for solar farms location (Asakereh et al., 2014). This paper presents a study that aimed at establishing a model that combines multiple data and criteria with GIS to selection optimal sites for PV installation and to quantify the amount of $\mathrm{CO}_{2}$ reduction in Peninsular Malaysia.

\section{Materials and Methods}

\section{Study Area}

Figure 1 presents the study area. Selangor is one of the 11 states in Peninsular Malaysia. The location of Selangor is within latitude $3.519863 \mathrm{~N}$ and longitude 101.538116E and has nine districts.

It is bounded to the north by Perak, Pahang to the East, Negeri Sembilan to the south and the Strait of Melaka to the west. Selangor is the most populous state in Malaysia with 5,411,324 inhabitants and has experienced rapid development due to modernization (Yusuf et al., 2014). Economically, the state takes the lead with GDP of RM 128.815 billion (roughly USD 42 billion) in 2014 making up 23\% of the whole Malaysian GDP. The state has a high standard of living and lowest poverty rate (MDS, 2010).

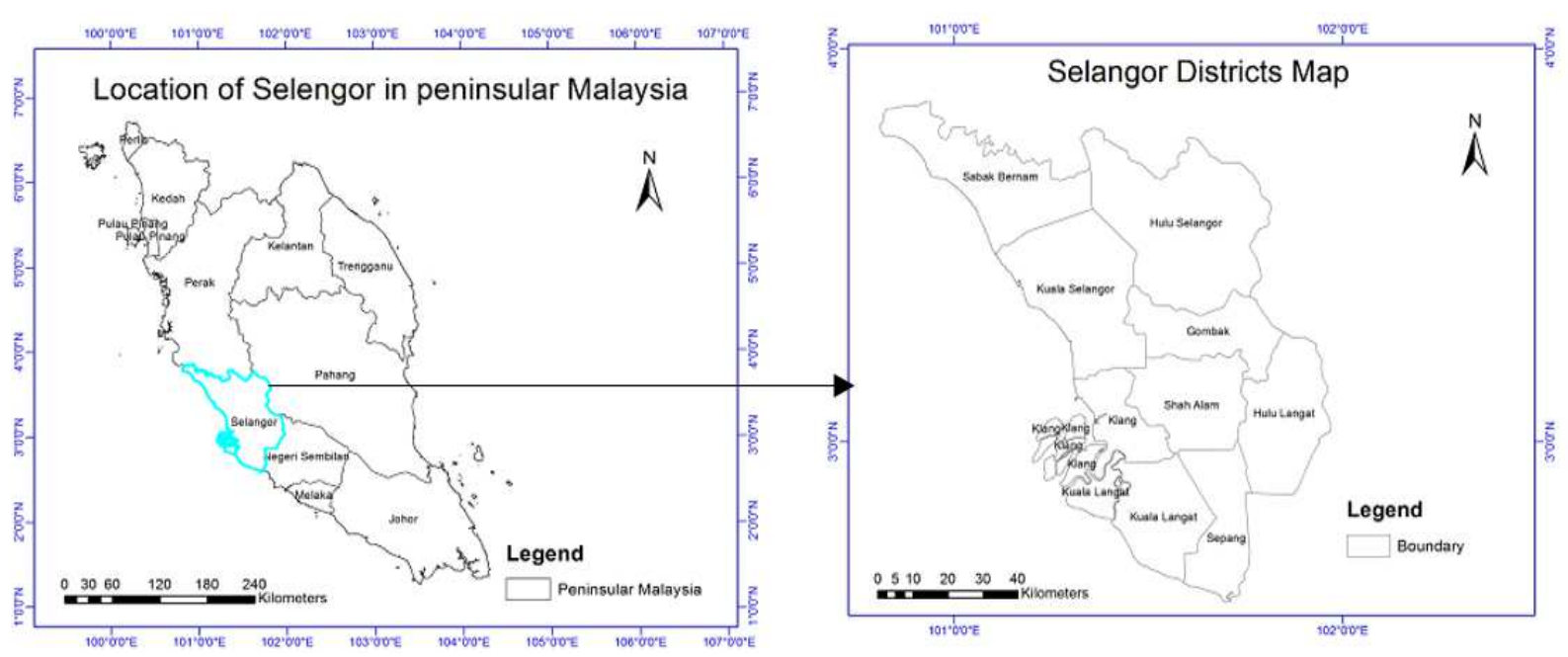

Fig. 1. Geographical position of the case study 


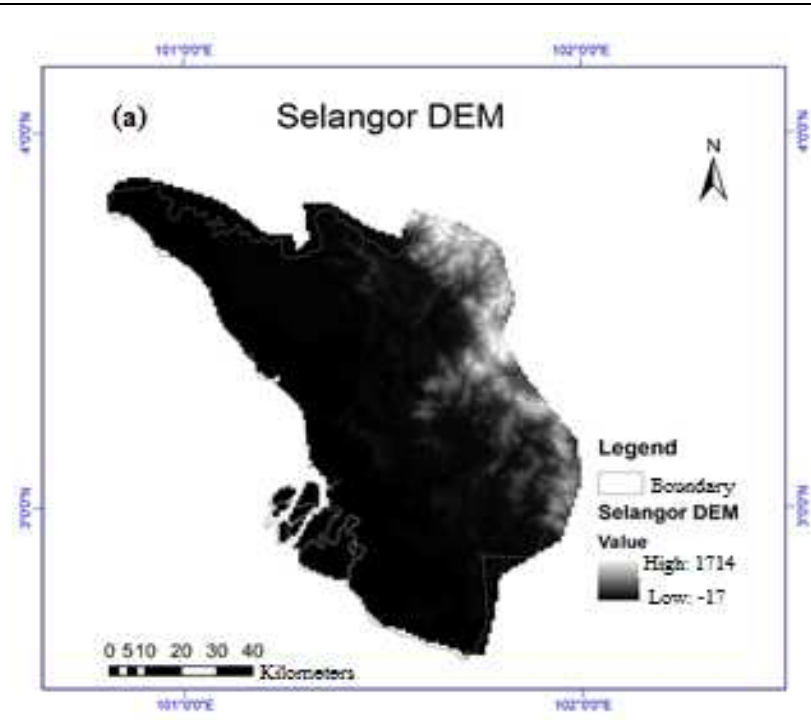

stroere

terones
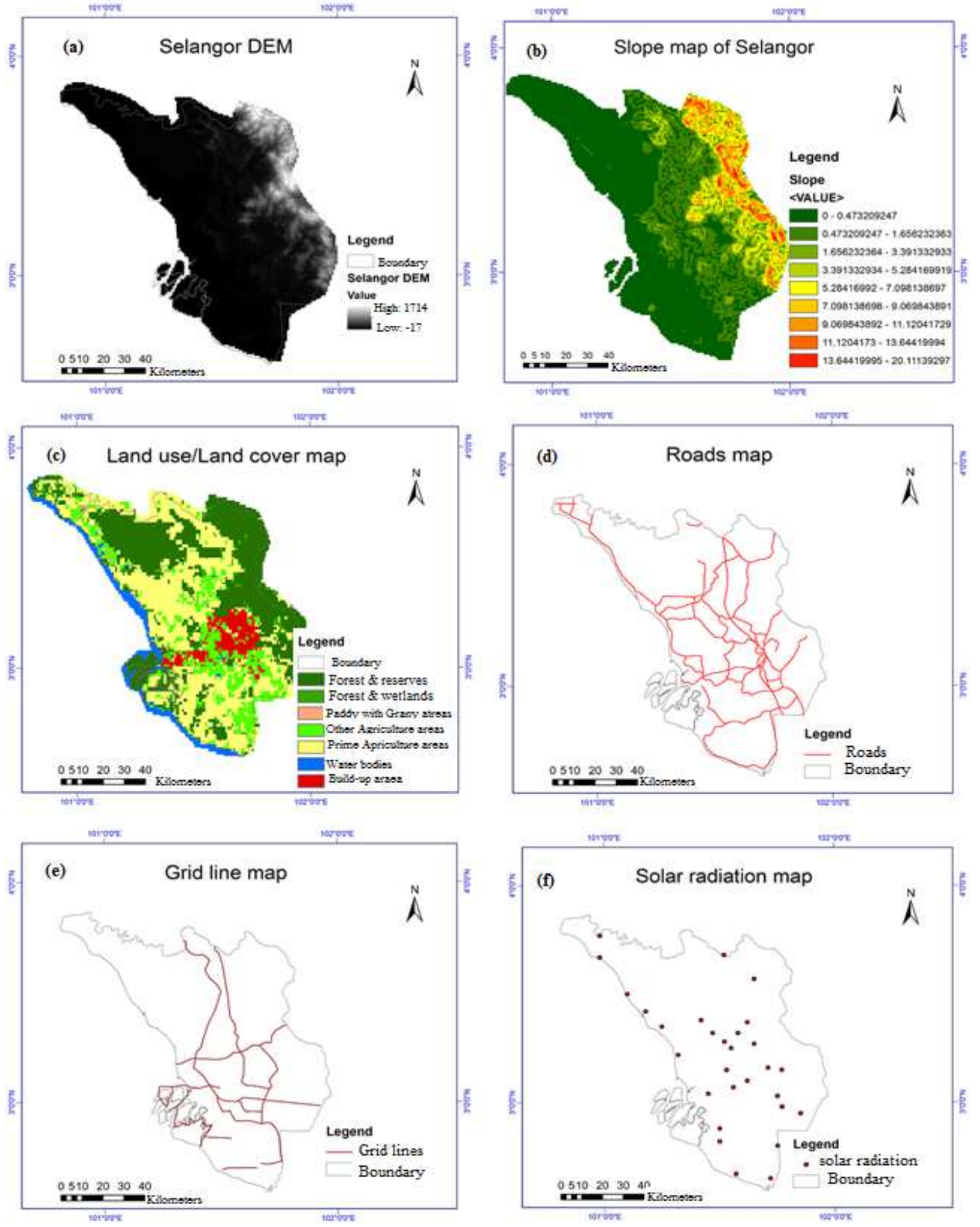

Fig. 2. Input datasets: (a) DEM of Selangor, (b) slope derived from DEM, (c) land use/land cover, (d) road networks, (e) grid lines and (f) solar radiation 


\section{Datasets and Criteria Definition}

This study uses different datasets from various sources. Table 1 presents the datasets, their sources and criteria definition. Elevation data (SRTM $30 \mathrm{~m}$ ), land cover and vector data (roads/highway and administrative boundary) where downloaded from Diva-gis (divagis.org). NASA provided the solar radiation data and the power transmission network/grid lines data were obtained from Tenaga National Berhad Malaysia (TNB, 2014). According to Sener et al. (2010), the choice of selection criteria may differ from one region to another based on local topography and other legal and environmental conditions. In this study, the parameters considered are slope, elevation, distance from roads, distance from $\mathrm{grid} /$ transmission lines and land use.

Solar radiation offers information of solar energy prospect at the site of interest (Funabashi, 2011). Longterm average solar irradiance is the main factor required for large-scale PV power plant installation and connection (Tisza, 2014). For an area to be optimal, the elevation must be less than or equal to $60 \mathrm{~m}$ and slope must not be greater than $5^{\circ}$ for all aspects (orientation). The slope of an area influences the incoming radiation i.e., the flatter the slope the more incoming solar radiation and hence the more suitable for PV installation (Tisza, 2014). However, Charabi and Gastli (2011) suggests that slope less than $5^{\circ}$ and facing south is the best. Within the study area, certain land use types are marked prohibited land for use. They include built-up areas, water bodies, forest and reserves, wetlands, paddy and granary areas. These areas were let off because of economic and environmental interests (Sánchez-Lozano et al., 2013). Fig. 2 shows the datasets used as input into the model.

Accessibility is a paramount necessity to save the cost of infrastructural development. Therefore, consideration is given to proximity to roads and existing grid, for ease of access during assemblage, installation, maintenance and as well as disassembling at the end of the lifespan of the PV (Tisza, 2014). Land requirement for smart large-scale PV installation has a standard, usually measured in acreage. As a rule, 3.31 acres must be available for $1 \mathrm{MW}$ PV power plant (Ong et al., 2013). In this study, we pegged average land area needed for a $50 \mathrm{MW}$ PV capacity to 165 acres.

\section{Data Processing}

Data processing passed through some stages in hierarchy as presented in Fig. 3 .

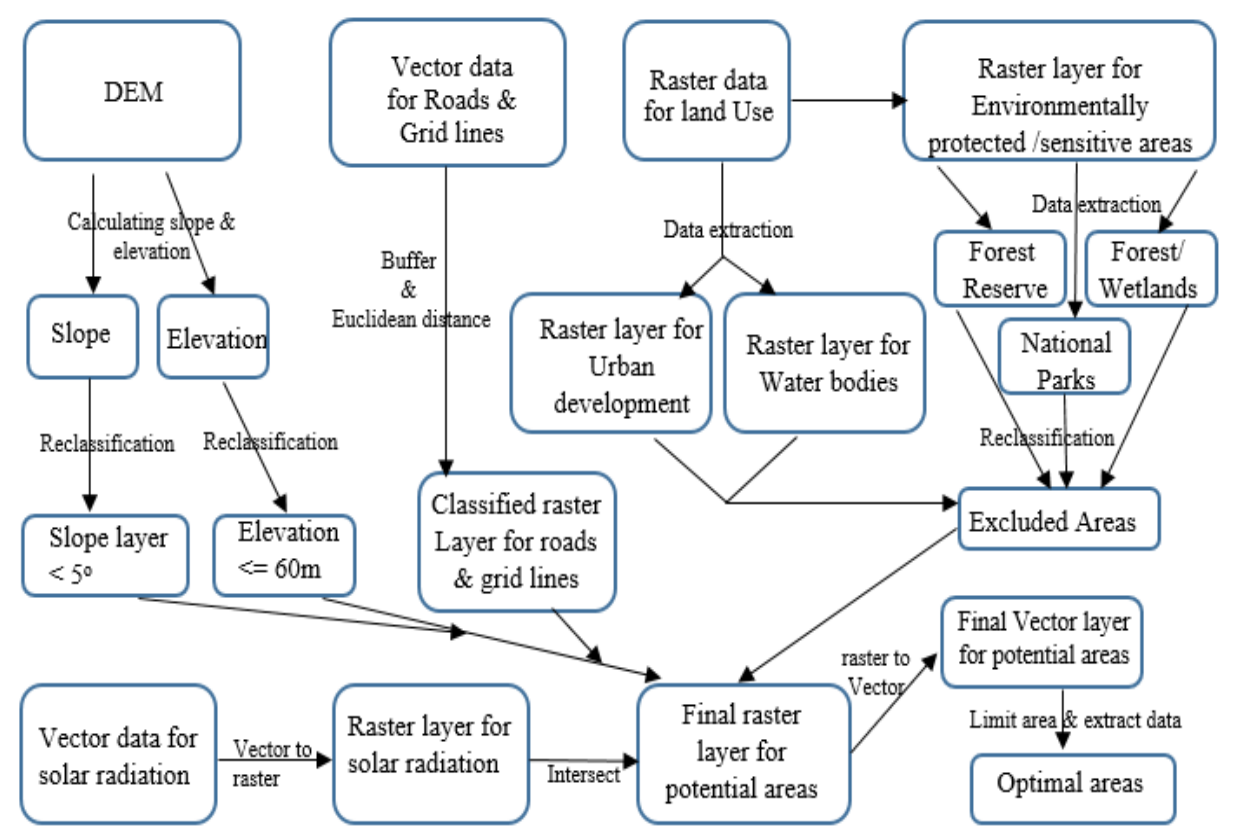

Fig. 3. The model developed for optimal site selection suitable location for large-scale smart grid-connected PV plants

Table 1. Data, sources and criteria used

\begin{tabular}{lll}
\hline Variable & Source & Criteria \\
\hline Elevation (DEM) & Diva GIS & Slope $<5^{0}$ Elevation $<60 \mathrm{~m}$ \\
Land cover & Diva GIS & Extraction of certain Land Use type \\
Roads & Diva GIS & $>500 \mathrm{~m}$ and $\leq 5,000 \mathrm{~m}$ \\
Grid lines & TNB Malaysia & $>500 \mathrm{~m} \leq 5,000 \mathrm{~m}$ \\
Solar radiation & NASA & Classified \\
Land requirement & - & $\geq 165$ acre \\
\hline
\end{tabular}




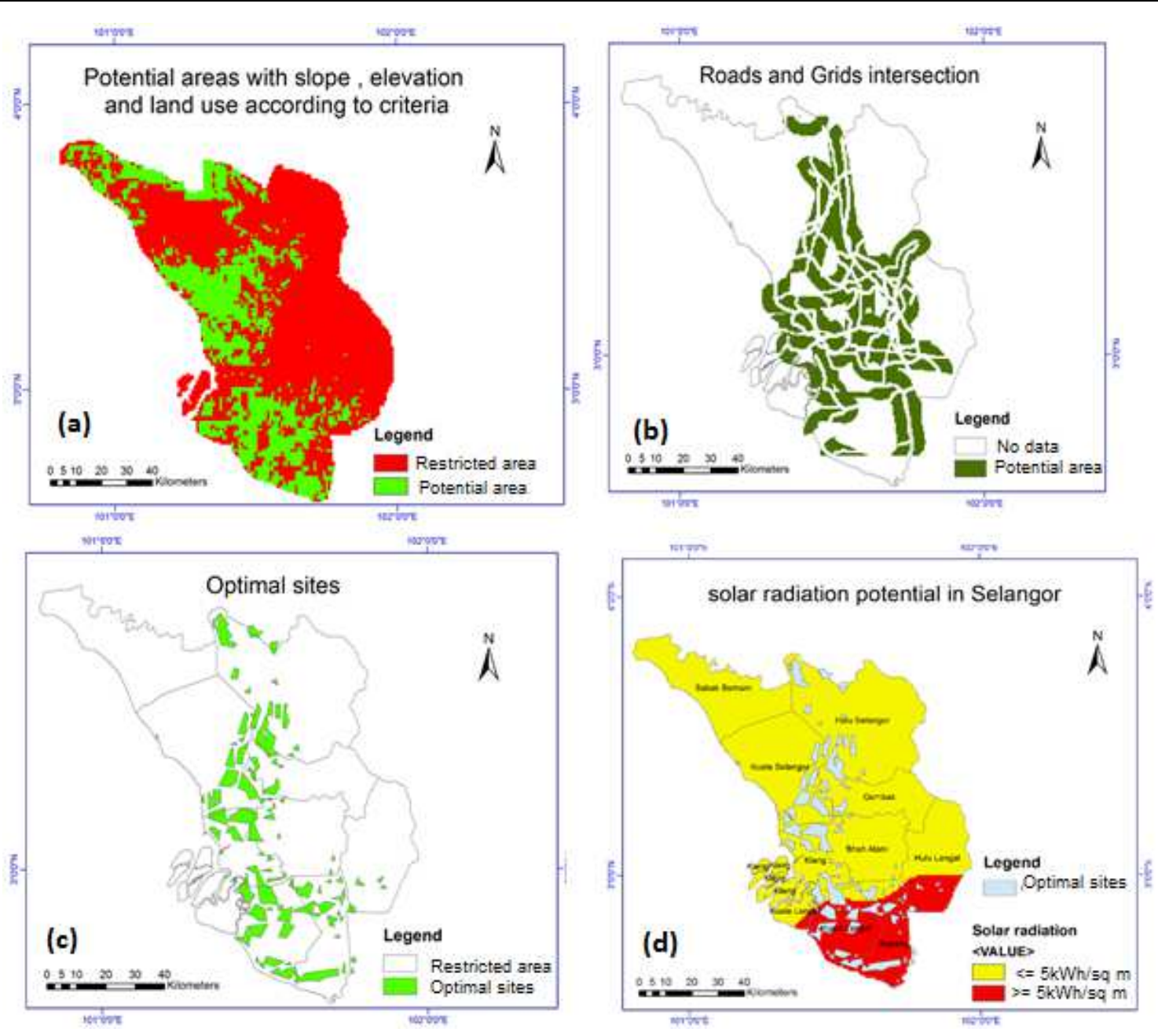

Fig. 4. Output dataset showing: (a) potential areas, (b) roads and grid intersection, (c) optimal sites map and (d) optimal sites overlaid on reclassified solar radiation

First, slope and elevation were derived from the DEM data where areas less than $60 \mathrm{~m}$ in elevation and slope less than or equal to $5^{\circ}$ were extracted using raster calculator. From land use map, prohibited lands (built up area, water bodies, forest and reserves, wetlands, paddy and granary areas) were masked out. The three outputs from this operation were overlaid to generate area outside the prohibited land. Moreover, that has lowelevation (less than or equal to $60 \mathrm{~m}$ ) and with a slope less or equal to $5^{\circ}$ (Fig. $4 \mathrm{a}$ ).

Second, the road and grid networks were converted to raster data file using Euclidean distance tool and reclassified. The resulting raster data was usable during which buffer operation was done to delineate land areas less than or equal to $500 \mathrm{~m}$ and those between 500 and $5000 \mathrm{~m}$ respectively. From this operation, we can exclude land area within 500 to road and grid line as unsuitable and those between 500 and $5000 \mathrm{~m}$ as suitable (Fig. 4b).

The third step integrates the results of first and second steps using overlaid function. From where we obtained areas close to the grid, close to the road, almost on the flat ground and of low elevation. Also, the resulting output was vectorized (raster to polygon conversion). Using selection tool areas greater than 165 acres were selected to obtain areas that are large enough for $50 \mathrm{MW}$ and above PV installation. With clip function, the suitable areas were divided by district (Fig. 4c).

Having done with the physical parameters, we processed the solar radiation obtained from NASA, which came as point data comprising of 30 locations across Selangor.

The initial step was to interpolate the data using kriging interpolation method, to provide solar radiation for unsampled positions. Further, the interpolated solar radiation was reclassified into two classes, that is, areas with solar radiation potential $\leq 5 \mathrm{kWh} / \mathrm{m}^{2}$ and areas $\geq$ $5 \mathrm{kWh} / \mathrm{m}^{2}$. The result was overlaid with the output of step three above to evaluate annual energy generation potential, installation capacity and carbon emission reduction (described in section 2.4) (Fig. 4d). Finally, the result was validated qualitatively by overlaying the final output on the 
hills hade of the study area so show the agreement of the model with physical criteria considered (Fig. 6).

\section{Predicting Annual Energy Generation Potential, Installation Capacity and $\mathrm{CO}_{2}$ Emission Reduction}

The next step after optimal sites selection is the predictive estimation of energy generation potential, installation capacity and $\mathrm{CO}_{2}$ emission reduction for each district. First, annual energy generation potential was calculated using the total area exposed to solar radiation (packing factor) of 0.5, optimal areas, average annual solar radiation and panel efficiency (15\%). The expressions used to estimate the annual electricity generation potential and installation capacity are Equation 1 and 2 (Charabi and Gastli, 2011; Gastli and Charabi, 2010):

$E G P=O A \times P F \times A S R \times P E$

$I C=E G P / A S R$

Where:

$E G P=$ The energy generation potential $(\mathrm{GWh} / \mathrm{yr})$

$O A=$ The total optimal areas $\left(\mathrm{km}^{2}\right)$

$P F=$ The parking factor (unitless)

$A S R=$ The annual solar radiation $\left(\mathrm{kWh} / \mathrm{m}^{2} / \mathrm{yr}\right)$

$P E=$ The panel efficiency $(\%)$

$I C=$ The installation capacity $(\mathrm{GW})$

The effect on the environment due to energy generation determines the carbon emission intensity per unit energy generated (Nelson et al., 2014). Annual $\mathrm{CO}_{2}$ emission reduction is estimated using Equation 3 (Kawase et al., 2013):

$E R_{\mathrm{CO}_{2}}=\mathrm{RF}_{\mathrm{CO}_{2}} \times E G P$

Where:

$R F_{\mathrm{CO}_{2}}\left(\mathrm{k} \mathrm{t}-\mathrm{CO}_{2} / \mathrm{kWh}\right)=$ The $\mathrm{CO}_{2}$ emission reduction factor $E G P$ $=$ previously defined

Carbon emission reduction factor, $R F_{\mathrm{co}_{2}}$, differs from one region to another (Design et al., 2006; IEA, 2006). Table 2 presents the carbon emission factor for different provinces in Malaysia.

The baseline emission factor also differs for different regions (Design et al., 2006) which can be obtained using Equation 4 (Design et al., 2006):

$$
E F=E F_{O M} \times \omega_{O M}+E F_{B M} \omega_{B M}
$$

Where:

$E F_{O M} \quad=$ The operating margin $\mathrm{CO}_{2}$ emission factor

$E F_{B M} \quad=$ The build margin $\mathrm{CO}_{2}$ emission factor

$\omega_{O M}$ and $\omega_{B M}=$ The weighting of operating margin emission factor and that of build margin
Table 2. Emission reduction factor

\begin{tabular}{ll}
\hline Grid system & $\begin{array}{l}\text { Carbon emission factor } \\
(\mathrm{kgCO} / \mathrm{kWh})\end{array}$ \\
\hline Peninsular Malaysia & 0.63 \\
Sarawak & 1.12 \\
West of Sabah & 0.65 \\
East Sabah & 0.80 \\
\hline
\end{tabular}

\section{Results}

This section presents the results of the previous stage of data processing train. Fig. 4 shows the end products of each level of data processing steps. Fig. 4a reveals the potential and restricted areas, in green and red colors respectively. Fig. $4 \mathrm{~b}$ depicts the intersection of road and power transmission lines with the feasible areas that fall outside $500 \mathrm{~m}$ proximity constraints shown in green color. The overlay of Fig. $4 \mathrm{a}$ and $4 \mathrm{~b}$ results in the extraction of optimal sites that fulfilled all the selection criteria as presented in Fig. 4c. The interpolated solar radiation reclassified to two classes, $\leq 5 \mathrm{kWh} / \mathrm{m}^{2}$ in yellow and $\geq 5 \mathrm{kWh} / \mathrm{m}^{2}$ in red colors respectively, as shown in Fig. 4d with the output of Fig. 4c overlaid. The intersection of optimal sites and solar radiation is translated to statistical values according to districts in the study area. This information was useful for extracting land requirement and the output presented in Table 3, expressed as a function of solar radiation class and percentage of land area.

The results of the expressions in Equation 1-3 quantified energy generation potential, installation capacity and carbon emission reduction. For visualization, the graphs in Fig. 5a-d were produced to highlight the statistical analysis. Finally, Fig. $6 \mathrm{a}$ and $6 \mathrm{~b}$ presents the qualitative validation of the model with results overlaid on the (a) shaded relief (b) land use/land cover map of the study area.

\section{Discussion}

From the results presented above, about $40 \%$ of the entire study area meets the initial criteria. That is have elevation below $60 \mathrm{~m}$, slope less than $5^{\circ}$ and land use and land cover outside the prohibited land use types (Fig. 4a). These areas are spatially varied, predominantly in the north and southwestern side of the study area. In Fig 4b, the potential areas are further streamlined based on other criteria - proximity to road and grid network. The prospective areas concentrate along these linear features (roads and grid lines). According to Tisza (2014), siting PV plant close to roads and grid lines reduce construction cost and transmission losses.

Optimal site derivation (Fig. 4c) comes from the intersection of both physical and proximity criteria. These areas are the most suitable and large enough to accommodate large-scale power plant installation. 
However, the interaction of these optimal sites vis-à-vis solar radiation is paramount to other derivatives such as installation capacity, energy generation potential and carbon emission. Solar resource potential (Fig 4d) shows two distinct spatial patterns. The higher radiation potential in the southern part of the study area has radiation $>5 \mathrm{kWh} / \mathrm{m}^{2}$ and the remaining part has radiation $<5 \mathrm{kWh} / \mathrm{m}^{2}$. However, this may be due to two main reasons; one, the topography and two, solar radiation orientation. In Tisza (2014), it was reported that slope influences the intensity of the solar radiation of a particular site. In this study, it can be observed that the topography of the southern side is relatively flatter than the north. Again, the sun orientation is more to the south-eastern direction. Looking at the entire study area, by industry standard, the solar radiation potential is good enough for solar PV installation.

Based on the National Renewable Energy Laboratory (NREL) classification, solar resource potential are in four classes: Moderate $\left(<4 \mathrm{kWh} / \mathrm{m}^{2} / \mathrm{day}\right)$, good $(>4-5$ $\mathrm{kWh} / \mathrm{m}^{2} /$ day $)$, very good $\left(>5-6 \mathrm{kWh} / \mathrm{m}^{2} /\right.$ day $)$ and excellent ( $>6-7 \mathrm{kWh} / \mathrm{m}^{2} /$ day (Funabashi, 2011). The contribution of this study to the field of science as well as its relevance to the socio-economic development of the case study is commendable.

Table 3 presents the distribution of optimal sites based on solar radiation for each district (Fig. 4d). From the figure, Kuala Langat has the largest optimum site area with 46644.59 acres, corresponding to $23.87892 \%$ of the overall optimal locations (Table 3). This is followed by Hulu Selangor with 35091.18 acres that constitute about $17.96434 \%$. Gombak has the least optimal land area with 9207.611 acres equivalent to

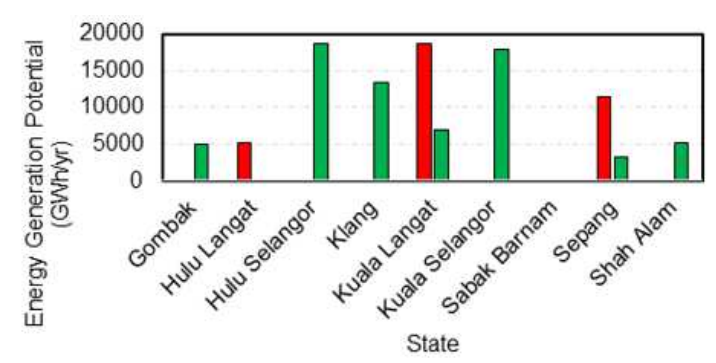

(a)

$\because \mathrm{SR}>5 \quad \square \mathrm{SR}<5$

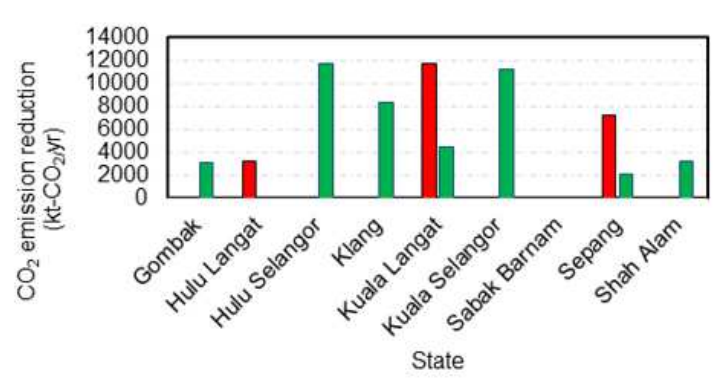

(c)
$4.713683 \%$. Although the districts have varying land areas, it does not always make them the most suitable in terms of solar radiation. For instance, Kuala Langat is about the same optimal area with the Hulu Selangor and Kuala Selangor but possess higher radiation potential than both of them.

By implication, Kuala Langat, Hulu Selangor and Kuala Selangor have almost equal Energy Generation Potentials (EGP) around $18600 \mathrm{GWh}$ annually (Fig 6a) whereas other districts fall within 4800-13000 GWh. Of course total energy generation potential depends on the installation capacity, so the distribution of installation capacity among the district (Fig.6b) maintained similar pattern as the other parameters (optimal site area and EGP). Kuala Langat, Hulu Selangor and Kuala Selangor have highest installation capacity of around $12 \mathrm{GW}$. The remaining districts have installation capacity within the range of 2.8 and $7.6 \mathrm{GW}$.

It is unrealistic to assume that a system with lower energy generation potential will produce higher $\mathrm{CO}_{2}$ emission reduction, as shown in Fig $6 \mathrm{c}$ and $\mathrm{d}$. In this study, the three districts with the largest area and highest energy generation potential (Kuala Langat, Hulu Selangor and Kuala Selangor) also produce higher $\mathrm{CO}_{2}$ emission reduction potential around $12000 \mathrm{kt}-\mathrm{CO}_{2} / \mathrm{yr}$. Others have emission reduction value ranging between $3000-8000 \mathrm{kt}-$ $\mathrm{CO}_{2} / \mathrm{yr}$. It implies that with this computation, an annual $\mathrm{CO}_{2}$ emission reduction of $66324 \mathrm{kt}-\mathrm{CO}_{2} / \mathrm{yr}$ is achievable in Selangor. As predicted 500 megatons carbon emission by the year 2030 (Ang et al., 2013) Selangor alone will be able to offset $331.62 \mathrm{Mt}-\mathrm{CO}_{2}(66.32 \%)$ of the predicted value for the year 2020 .

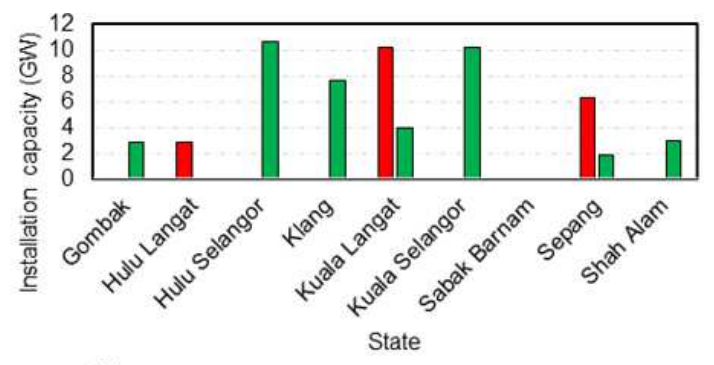

(b)

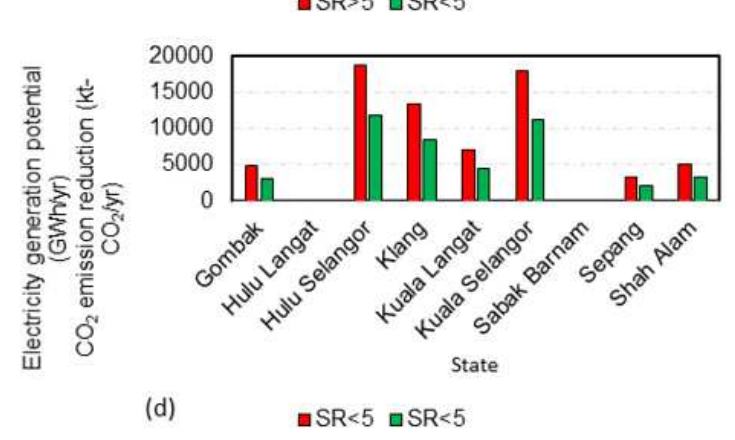

Fig. 5. Technical analysis based on the land requirement and solar radiation potential in districts: (a) EGP, (b) IC, (c) $\mathrm{CO}_{2}$ emission reduction and (d) EGP and $\mathrm{CO}_{2}$ emission reduction 

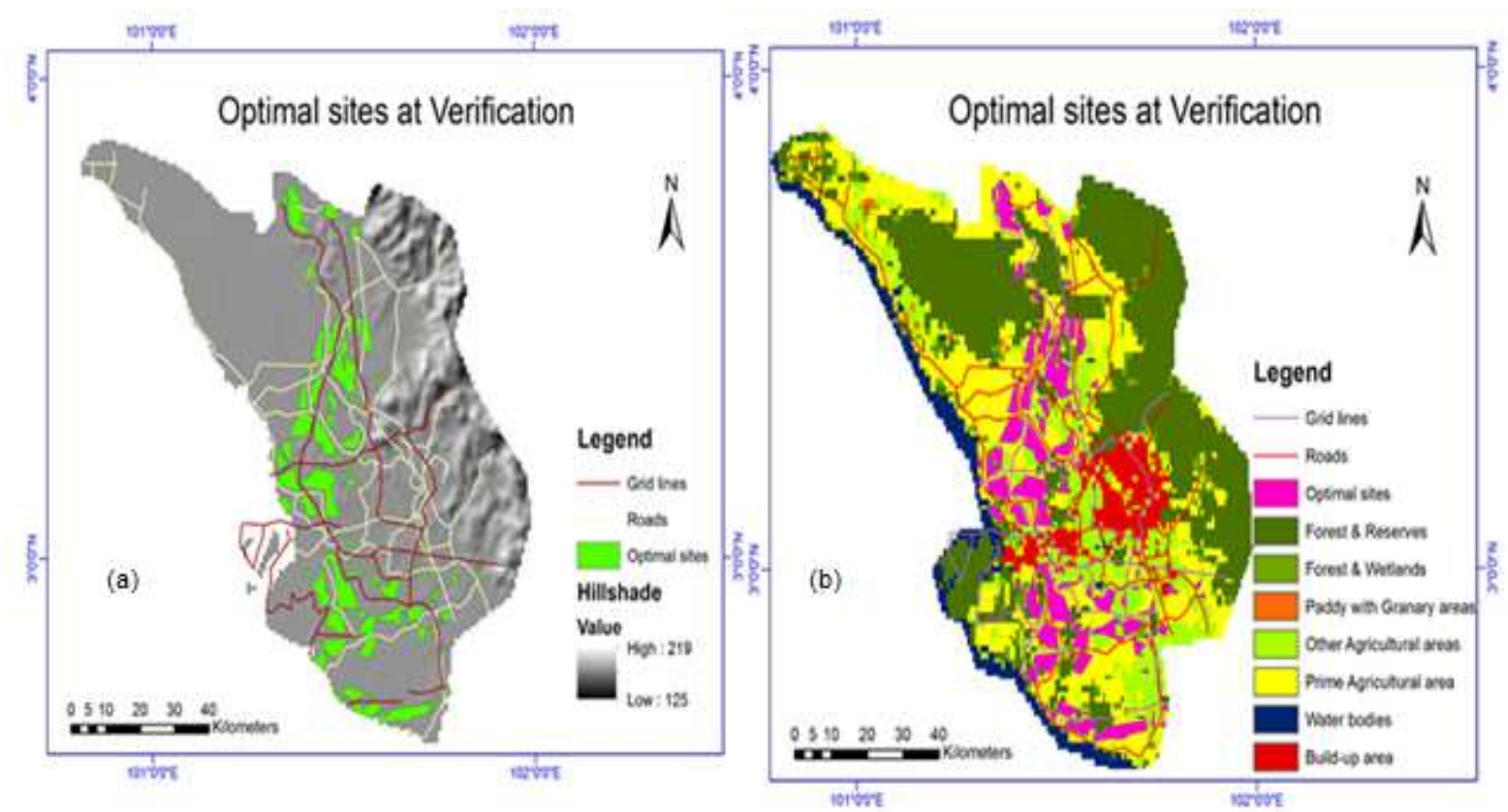

Fig. 6. Result validation: (a) Optimal sites with roads and grid lines overlaid on hillshade and (b) optimal sites, road network and grid lines overlaid on land use map

Table 3. Land requirement of optimal sites according to the districts

\begin{tabular}{lllllll}
\hline & Area (acre) & Area (acre) & & Land area (\%) & Land area (\%) \\
Districts & SR $\geq 5$ & SR $\leq 5$ & Total area (acre) & SR $\geq 5$ & Total (\%) \\
\hline Gombak & 0 & 9207.6112 & 9207.611 & 0 & 4.713683 & 4.71 \\
Hulu Langat & 9291.5569 & 0 & 9291.557 & 4.756657 & 0 & 4.76 \\
Hulu Selangor & 0 & 35091.176 & 35091.18 & 0 & 17.96434 & 17.96 \\
Klang & 0 & 25016.149 & 25016.15 & 0 & 12.8066 & 12.81 \\
Kuala Langat & 33517.221 & 13127.372 & 46644.59 & 17.15858 & 6.720339 & 23.88 \\
Kuala Selangor & 0 & 33561.874 & 33561.87 & 0 & 17.18144 & 17.18 \\
Sabak Barnam & 0 & 0 & 0 & 0 & 0 & 0 \\
Sepang & 20673.513 & 6176.664 & 26850.18 & 10.58346 & 3.16204 & 13.75 \\
Shah Alam & 0 & 9674.8085 & 9674.808 & 0 & 4.952857 & 4.95 \\
Total & 63482.3 & 131856 & 195338 & 32.4987 & 67.5013 & 100 \\
\hline
\end{tabular}

From all indication, this model performs well for optimal site selection for large-scale PV installation by using the spatial and technical factors. Similarly, Fig 5a and $5 \mathrm{~b}$ shows that all criteria considered in this study agree with the conditions applied.

\section{Conclusion}

This paper presents a proposed model for optimal sites selection for large scale smart grid-connected PV power plants in Selangor, Malaysia. The results achieved demonstrated the effectiveness of the proposed model in providing the precise location of suitable areas for largescale PV power plant installation. The results presented showed excellent potentials of large-scale PV electricity generation. Also, accurate estimation of three other significant parameters that include energy generation potential, installation capacity and $\mathrm{CO}_{2}$ emission reduction, were derived. The analysis proves the robustness of GIS as a viable decision support tool in renewable energy planning and environmental management. Overall, the study reveals the contribution of PV to provide relief on constrained energy demand and $\mathrm{CO}_{2}$ emission reduction.

\section{Acknowledgement}

The authors proudly acknowledge the support from the following data sources toward successful completion of the study: Diva-gis.org, NASA Surface Meteorology and Solar Energy and Tenaga National Berhad (TNB) Malaysia.

\section{Author's Contributions}

Sabo Mahmoud Lurwan: Involved in data collection, processing and analysis as well as manuscript drafting.

Norman Mariun: Provide project leadership and supervision of the research. 
Mohammed Oludare Idrees: Analysis and manuscript preparation.

Goma Bedawi Ahmed and Usman Salihu Lay: Involved in data collection and analysis.

\section{Ethics}

This article is original and contains unpublished material. The corresponding author confirms that all of the other authors have read and approved the manuscript and no ethical issues involved.

\section{References}

Affandi, R., M. Ruddin, A. Ghani and C.K. Gan, 2013. A review of Concentrating Solar Power (CSP) in Malaysian environment. Int. J. Eng. Adv. Technol., 3: 378-382.

Ahmad, S., M.Z.A.A. Kadir and S. Shafie, 2011. Current perspective of the renewable energy development in Malaysia. Renewable Sustainable Energy Rev., 15: 897-904. DOI: 10.1016/j.rser.2010.11.009

Ali, R., I. Daut and S. Taib, 2012. A review on existing and future energy sources for electrical power generation in Malaysia. Renewable Sustainable Energy Rev., 16: 4047-4055. DOI: 10.1016/j.rser.2012.03.003

Amirruddin, A.K., M.M. Noor, K. Kadirgama and K.V. Sharma, 2011. The potential of wind and solar energy in Malaysia east coast: Preliminary study at Universiti Malaysia Pahang (UMP). Trans. Wessex Insititute. DOI: 10.2495/RAV110431

Ang, C.T., N. Morad, X.M.T. Morad and N. Ismail, 2013. Projection of carbon dioxide emissions by energy consumption and transportation in Malaysia: A time series approach. J. Energy Technol. Policy, 3: 63-75.

Asakereh, A., M. Omid, R. Alimardani and F. Sarmadian, 2014. Developing a GIS-based fuzzy AHP model for selecting solar energy sites in Shodirwan region in Iran. Int. J. Adv. Sci. Technol., 68: 37-48.

DOI: $10.14257 /$ ijast.2014.68.04

Charabi, Y. and A. Gastli, 2011. PV site suitability analysis using GIS-based spatial fuzzy multi-criteria evaluation. Renewable Energy, 36: 2554-2561.

DOI: 10.1016/j.renene.2010.10.037

Chen, W., 2012a. Renewable energy status in Malaysia. SEDA Malaysia.

Chen, W., 2012b. Renewable energy status in Malaysia SEDA Malaysia.

Chua, S.C. and T.H. Oh, 2010. Review on Malaysia's national energy developments: Key policies, agencies, programmes and international involvements. Renewable Sustainable Energy Rev., 14: 2916-2925. DOI: 10.1016/j.rser.2010.07.031

Design, P., D. Form, C.D.M. Pdd and E. Board, 2006. Clean Development Mechanism Project Design Document Form (CDM-PDD) version 03-in effect as of: 28 July 2006.
EDGAR, 2013. Emission database for global atmospheric researc: $\mathrm{CO}_{2}$ time series $1990-2013$ per region/country. EDGAR.

Energy-Commission, 2014. Peninsular Malaysia electricity supply industry outlook 2014. Suruhanjaya Tenaga.

Funabashi, T., 2011. A GIS approach for estimating optimal sites for grid-connected Photovoltaic (PV) cells in Nebraska. University of Nebraska, Lincoln.

Gastli, A. and Y. Charabi, 2010. Solar electricity prospects in Oman using GIS-based solar radiation maps. Renewable Sustainable Energy Rev., 14: 790-797. DOI: 10.1016/j.rser.2009.08.018

IEA, 2006. Compared assessment of selected environmental indicators of photovoltaic electricity in OECD cities. International Energy Agency.

IEA, 2014. Trends 2014 in photovoltaic applications survey: Survey report of selected IEA countries between 1992 and 2013.

Kawase, M., K. Okajima and Y. Uchiyama, 2013. Evaluation of potential geographic distribution for large-scale photovoltaic system in suburbs of China. J. Renewable Energy. DOI: 10.1155/2013/106063

MDS, 2010. Gross Domestic Product (GDP) by State, 2010. Department of Statistics, Malaysia. Putrajaya, Malaysia.

Mekhilef, S., A. Safari, W.E.S. Mustaffa, R. Saidur and R. Omar et al., 2012. Solar energy in Malaysia: Current state and prospects. Renewable Sustainable Energy Rev., 16: 386-396. DOI: 10.1016/j.rser.2011.08.003

Nelson, J., A. Gambhir and N. Ekins-Daukes, 2014. Solar power for $\mathrm{CO}_{2}$ mitigation. Grantham institute for climate change.

Noh, C.K.M., 2012. Overview on the energy resources in Malaysia. Kuala Lumpure, Malaysia.

Ong, H.C., T.M.I. Mahlia and H.H. Masjuki, 2011. A review on energy scenario and sustainable energy in Malaysia. Renewable Sustainable Energy Rev., 15: 639-647. DOI: 10.1016/j.rser.2010.09.043

Ong, S., C. Campbell, P. Denholm, R. Margolis and G. Heath, 2013. Land-use requirements for solar power plants in the United StatesNational Renewable Energy Laboratory.

Sánchez-Lozano, J.M., C. Henggeler Antunes, M.S. García-Cascales and L.C. Dias, 2014. GIS-based photovoltaic solar farms site selection using ELECTRE-TRI: Evaluating the case for Torre Pacheco, Murcia, Southeast of Spain. Renewable Energy, 66: 478-494.

DOI: $10.1016 /$ j.renene.2013.12.038

Sánchez-Lozano, J.M., J. Teruel-Solano, P.L. Soto-Elvira and M. Socorro García-Cascales, 2013. Geographical Information Systems (GIS) and MultiCriteria Decision Making (MCDM) methods for the evaluation of solar farms locations: Case study in south-eastern Spain. Renewable Sustainable Energy Rev., 24: 544-556. DOI: 10.1016/j.rser.2013.03.019 
Şener, Ş., E. Şener, B. Nas and R. Karagüzel, 2010. Combining AHP with GIS for landfill site selection: A case study in the Lake Beyşehir catchment area (Konya, Turkey). Waste Manage., 30: 2037-2046. DOI: 10.1016/j.wasman.2010.05.024

Tisza, K., 2014. Gis-Based suitability modeling and multi-criteria decision analysis for utility scale solar plants in four states in the southeast US. Clemson University.

TNB, 2014. Energy planning challenges: From TNB perspective. Regulatory Economics and Planning Division.

Uyan, M., 2013. GIS-based solar farms site selection using Analytic Hierarchy Process (AHP) in Karapinar region, Konya/Turkey. Renewable Sustainable Energy Rev., 28: 11-17. DOI: 10.1016/j.rser.2013.07.042
Van Haaren, R. and V. Fthenakis, 2011. GIS-based wind farm site selection using Spatial Multi-Criteria Analysis (SMCA): Evaluating the case for New York State. Renewable Sustainable Energy Rev., 15: 3332-3340. DOI: 10.1016/j.rser.2011.04.010

Wee, K., H. Matsumoto, S. Chin and F. Yu, 2008. Energy consumption and carbon dioxide emission considerations in the urban planning process in Malaysia. J. Malaysian Institute Planners, 6: 99-128.

Yusuf, Y.A., B. Pradhan and M.O. Idrees, 2014. Spatiotemporal assessment of urban heat Island effects in Kuala Lumpur metropolitan city using Landsat images. J. Ind. Society Remote Sens., 42: 829-837. DOI: $10.1007 / \mathrm{s} 12524-013-0342-8$

Zeman, M., 1987. Solar Cells: Introduction to Solar Electricity. In: Introduction to Photovoltaic Solar Energy, Oxford University Press, New York, pp: 1-13. 